Майстренко О. В. к.військ.н.

Кафедра ракетних військ i артилерії командно-штабного інституту застосування військ (сил) Національного університету оборони України імені Івана Черняховського, Київ

\title{
Подальший розвиток принципу масування ракетних військ і артилерії, їх ударів і вогню на найважливіших напрямках
}

\begin{abstract}
Резюме. Стаття присвячена подальшому розвитку принципу масування ракетних військ і артилерії, ï ударів i вогню на найважливіших напрямках 3 урахуванням особливостей внутрішніх воєнних конфліктів останнього часу, що грунтується на дослідженні функціонально-організаційних ланцюгів системи вогневого ураження противника з урахуванням послідовності виконання функціональних завдань (за теорією Бойда) окремими підсистемами вогневого ураження противника.
\end{abstract}

Ключові слова: ракетні війська і артилерія, вогневе ураження противника, принцип масування.

Постановка проблеми. Результати аналізу бойового застосування ракетних військ і артилерії (РВіА) у воєнних конфліктах останнього часу [1-5] свідчать про певні проблеми, які суттєво знижують ступінь реалізації можливостей $\mathrm{PBiA} \mathrm{щодо} \mathrm{вогневого}$ ураження противника (ВУП). Особливо відмітними ці проблеми $є$ для внутрішніх збройних конфліктів. До таких проблем відносяться - недостатній ефект від зосередження вогню артилерії на ділянках зосередження основних зусиль (в обороні) та ділянках прориву (у наступі), необхідність збільшення витрати боєприпасів для досягнення необхідного ступеня ураження противника. Означені проблеми викликані підвищенням маневреності об'єктів для ураження, ступенем розосередження об'єктів противника, підвищенням ступеня захищеності об' єктів противника.

У цілому ж, у практиці бойового застосування РВіА під час ВУП виникла певна невідповідність між необхідністю дотримуватись принципу масування (зосередження) PBiA, їх ударів і вогню на найважливіших напрямках (далі принцип масування) та необхідністю розосереджувати $\mathrm{PBiA,} \mathrm{їх} \mathrm{удари} \mathrm{i} \mathrm{вогонь} \mathrm{для} \mathrm{забезпечення}$ максимального впливу на противника.

Ступінь розробленості проблеми. Результати аналізу останніх досліджень i публікацій [6-9], присвячених питанню підвищення ступеню реалізації можливостей РВіА під час ВУП свідчать, що в переважній ïх більшості превалює думка про те, що принцип масування втрачає свою актуальність особливо у внутрішніх збройних конфліктах. Однак необхідно зазначити, що сама сутність принципу полягає у взаємопідсиленні впливу сукупності засобів на обмежену ділянку або по визначених об'єктах, що не втратило своєї актуальності.

Таким чином, виникла нагальна необхідність у переосмисленні та подальшому розвитку принципу масування. Тому метою статті $\epsilon$ подальший розвиток принципу масування PBiA, їx ударів i вогню на найважливіших напрямках 3 урахуванням особливостей внутрішніх воєнних конфліктів останнього часу.

Виклад основного матеріалу. Для переосмислення принципу масування пропонується розглянути його історичну ретроспективу розвитку і трансформації, що уможливить виявлення тенденцій цього процесу. Як відомо, принцип масування сил i засобів за час свого існування декілька разів суттєво трансформувався. Так, виникнувши як принцип масування живої сили на одному 3 флангів, за часів Епамінонда (418 - 362 рр. до н.е.) [10], передбачав лише створення косих фаланг у яких кількість солдат на лівому фланзі була більша ніж на правому, що було обумовлено зброєю та фізіологією (меч у правій руці, щит у лівій). 3 часом косі фаланги стали як лівобічні, так і правобічні, з'явилось масування самих фаланг на одному 3 флангів. Однак більшу зацікавленість викликає застосування означеного принципу 3 появою артилерії, адже з'явилась можливість масувати не тільки сили і засоби, а і вогонь.

За часів Наполеона Бонапарта (1769-1821 рр.) принцип масування дістав подальшого розвитку і зумовлював масування вогню артилерії на критичні точці диспозиції противника [11]. Однак трактування критичної точки не було достатньо точно визначено. 
Відмітним етапом подальшого розвитку принципу масування $\epsilon$ період Другої світової війни (битва за Дніпро, 1943 р.), де принцип дістав того класичного трактування, яке прийняте і сьогодні [12].

Загалом же історична ретроспектива принципу масування свідчить, що зі збільшенням розмаху бойового зіткнення концентрація уваги в трактуванні цього принципу зосереджувалась на тих критичних точках, від стійкості яких залежав успіх операції (бою). Окрім того, принцип масування враховував загальну технологічність процесу бойового зіткнення, тобто із появою нових видів озброєння означений принцип відображав характер їx застосування.

У цілому ж, сутність принципу масування полягає у взаємопідсиленні впливу тих чи інших видів сил і засобів на визначених ділянках або об'єктах противника.

Результати аналізу бойового застосування збройних формувань у військових конфліктах останнього часу [1-5] засвідчують, що структура збройних формувань та їх бойові порядки стали більш гнучкими, тобто набули здатності трансформуватися під впливом негативних умов і факторів, зберігаючи свій потенціал для подальших дій. Таким чином, для подолання такого противника необхідно забезпечити такий вплив на нього який за часом не перевищить часу реакції противника. Іншими словами, увесь необхідний обсяг впливу (загалом - вогневого впливу) необхідно здійснити до того часу поки противник не змінить своєї структури та (або) бойових порядків. Це загалом $є$ достатньо складною задачею, адже після зміни структури та (або) бойових порядків необхідно провести дорозвідку противника, спланувати порядок впливу на нього, що відповідає теорії висунутої Джоном Бойдом у 1995 році [13].

Сутність теорії Бойда полягає у повторюваному циклі спостереження оцінювання - рішення - дія (рис. 1). Відповідно, спрощене трактування цієї теорії перемагає та сторона у якої означений цикл займає менше часу [13]. Однак якщо розглядати $\mathrm{PBiA}$ як складну, ієрархічну, багатофункціональну систему необхідно зауважити, що кожен елемент цієї системи, як правило, виконує одну або декілька специфічних йому функцій, що загалом не впливає на противника напряму, однак значно підсилює або навіть уможливлює вплив на противника іншими засобами.

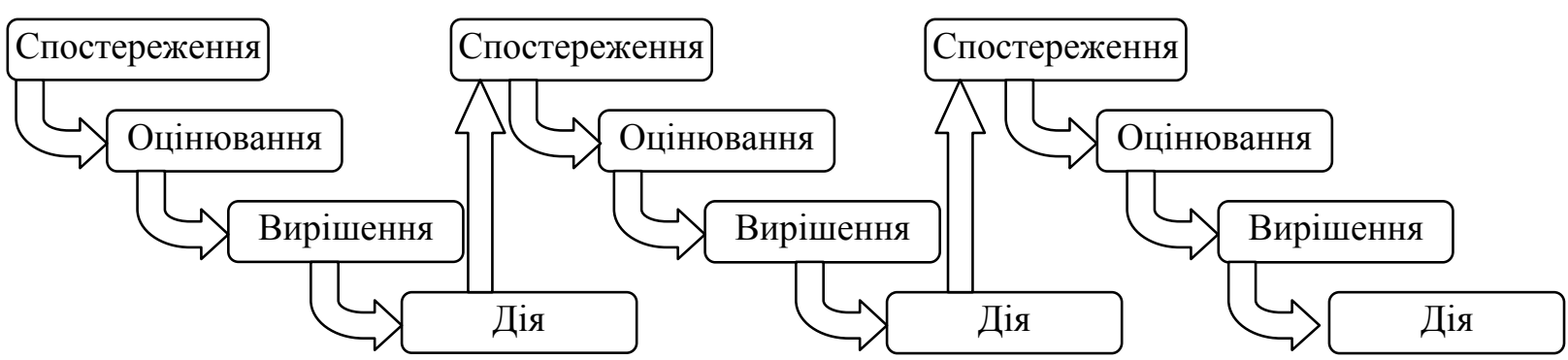

Рис. 1. Принципова схема реалізації теорії Бойда

Таким чином, якщо представити РBiА у розрізі функціональних зв'язків, то можна виявити, що більшість його структурних елементів відносяться до певних груп із певними функціями. Тобто функції спостереження - сили і засоби розвідки; оиінювання та прийняття рішення - сили $\mathrm{i}$ засоби управління; діï - сили і засоби вогневого впливу на противника.

Отже, якість інформаційних зв'язків між означеними функціональними елементами та вогневий вплив визначатимуть час проходження циклу виявлення-ураження. Однак необхідно зауважити на суттєвий аспект - перевагу однієї чи іншої сторони по часу циклу можливо визначати при умові рівномірного впливу сторін. Проте на практиці цього майже не відбувається. До того ж, імовірність успішної реалізації можливостей щодо виконання своїх функцій функціональними елементами РВіА не завжди, точніше майже ніколи, не дорівнює одиниці.

Таким чином, забезпечення необхідного обсягу впливу на противника до того часу допоки він не змінить своєї структури та (або) бойових порядків грунтуючись на зменшенні часу циклу виявлення-ураження є зрозумілим результатом але таким, що складно реалізувати.

3 іншого боку, означена теорія дає змогу припустити, що, внаслідок взаємопов'язаності функцій елементів РВіА, вплив на одну 3 них призведе до порушення інших. Тобто при впливі на одну 3 підсистем збройного формування противника його сумарні 
можливості щодо вогневого впливу знизяться на величину зменшення можливостей тієї підсистеми на яку був здійснений цілеспрямований вплив. Загалом, це відповідає закону найменших (слабкої ланки) [14], сутність якого полягає у тому, що можливості системи щодо реалізації своїх функцій залежить від можливостей елемента 3 найменшими можливостями.

Тобто, розглядаючи $\mathrm{PBiA,} \mathrm{як} \mathrm{складну}$ цілеспрямовану систему можна стверджувати, що їх можливості щодо вогневого впливу на противника визначаються тією підсистемою, яка має найменші можливості щодо реалізації своїх функцій. Однак, застосування закону найменших для умов вогневого впливу на противника потребує уточнення для врахування специфіки процесу. Визначення можливостей підсистем вогневого впливу противника є складним процесом, тому доволі часто доводиться приймати рішення на вогневий вплив в умовах невизначеності. Тому, при визначенні можливостей підсистем вогневого впливу противника необхідно враховувати не тільки їх можливості щодо реалізації своїх функцій, а й (особливо в умовах невизначеності) ступінь викриття об' єктів певної підсистеми.

Загалом же виходячи з функціональної придатності кожного елементу збройних формувань РВіА можна стверджувати, що зосередження впливу на одній із підсистем вогневого впливу противника призведе до суттєвого зниження його можливостей в цілому, а зосередження впливу на підсистемі 3 найменшими можливостями, до того ж мінімізує витрати (боєприпаси, операційний час) на досягнення переваги над противником.
Для демонстрації доцільності подальшого розвитку змісту принципу масування пропонується розглянути приклад. Вихідні дані (усереднені для умов прикладу): кількість засобів вогневого впливу противника - 12, кількість пунктів управління - 3, кількість засобів розвідки - 9. Причому імовірність розвідки об' єкта засобами розвідки противника - 0,8, а інтенсивність - 5 об/год, імовірність прийняття рішення на ураження об'єкта органом управління противника - 0,5, а інтенсивність - 10 об/год, імовірність ураження засобом вогневого впливу противника - 0,6, а інтенсивність - 4 об/год. Також пропонується припустити, що середня витрата боєприпасів для подавлення одного об'єкта противника складає 50 снарядів калібру 122 мм на гектар [15, табл. 22]. Завдання - забезпечити дії загальновійськових формувань шляхом завоювання вогневої переваги.

Пропонується розглянути декілька варіантів дій:

1 варіант - зосереджувати вогонь на визначеній ділянці лінії бойового зіткнення, де знаходяться: 9 засобів вогневого впливу противника, 2 пункти управління, 6 засобів розвідки;

2 варіант - зосереджувати вогонь на одній із підсистем - підсистемі розвідки;

3 варіант - зосереджувати вогонь на найслабшій за можливостями підсистемі підсистемі управління.

Загальні можливості противника пропонується визначити табличним способом (табл. 1). Очевидно, що загальні можливості противника щодо вогневого впливу на наші війська будуть обмежуватись підсистемою управління і відповідно не можуть перевищувати 15 завдань за годину.

Таблиця 1

Визначення можливостей підсистем вогневого впливу противника

\begin{tabular}{|l|c|c|c|c|}
\hline Підсистема ВУП & $\begin{array}{c}\text { Кількість } \\
\text { засобів, } \\
\text { од. }\end{array}$ & $\begin{array}{c}\text { Імовірність } \\
\text { успішного виконання } \\
\text { завдання }\end{array}$ & $\begin{array}{c}\text { Інтенсивність } \\
\text { виконання завдань } \\
\text { одним 3асобом, об/год }\end{array}$ & $\begin{array}{c}\text { Кількість успішно } \\
\text { виконаних завдань } \\
\text { за 1 годину, од. }\end{array}$ \\
\hline Вогневого впливу & 12 & 0,6 & 4 & 29 \\
\hline Управління & 3 & 0,5 & 10 & 15 \\
\hline Розвідки & 9 & 0,8 & 5 & 36 \\
\hline
\end{tabular}

Для кращого визначення різниці між варіантами ВУП пропонується взяти можливості наших військ такими ж, тобто за одну годину ми можемо уразити 15 об'єкти противника.

Результати дій за варіантами ВУП пропонується представити у вигляді таблиці (табл. 2).

Виходячи з умови задачі перший варіант ВУП не дасть змоги повністю подавити засоби противника за одну годину, адже на визначеній ділянці буде знаходитись 17 об'єктів, а можливості складають 15 об'єктів за годину. Таким чином, при ураженні лише тих об'єктів противника, які знаходяться на визначеній ділянці повністю подавити об' єкти противника не вдалось, тим більше, що противник може перегрупуватися і також буде впливати на наші війська. 
У другому та третьому варіантах вдалось повністю подавити систему ВУП, однак при ураженні найслабшої підсистеми (3 варіант) вдалось досягти мети із значно меншою витратою боєприпасів (економія 150 снарядів).

Зрозуміло, що у прикладі існує певне спрощення, однак він чітко свідчить про необхідність подальшого розвитку принципу масування.

Таким чином, загальна інтерпретація принципу масування пропонується така: зосереджувати зусилля $\mathrm{PBiA}$ щодо вогневого впливу на ті підсистеми противника, які мають найменші можливості, або найбільш розвідані.

Прогнозовані результати вогневого впливу на противника за трьома варіантами

\begin{tabular}{|c|c|c|c|c|c|c|c|}
\hline Підсистеми ВУП & $\begin{array}{c}\text { Кількість, } \\
\text { об }\end{array}$ & $\begin{array}{c}\text { Уражено, } \\
\text { об }\end{array}$ & $\begin{array}{l}\text { Витрата, } \\
\text { снарядів }\end{array}$ & $\begin{array}{c}\text { Залишилось, } \\
\text { об }\end{array}$ & \begin{tabular}{|c} 
Імовірність \\
виконання \\
завдання
\end{tabular} & $\begin{array}{c}\text { Інтенсивність } \\
\text { виконання } \\
\text { завдань }\end{array}$ & \begin{tabular}{|c|} 
Сумарні \\
можли- \\
вості, \\
вик. завд.
\end{tabular} \\
\hline \multicolumn{8}{|c|}{1 варіант } \\
\hline Вогневого впливу & 12 & 7 & 350 & 5 & 0,6 & 4 & 12 \\
\hline Управління & 3 & 2 & 100 & 1 & 0,5 & 10 & 5 \\
\hline Розвідки & 9 & 5 & 250 & 3 & 0,8 & 5 & 12 \\
\hline Разом & 24 & 15 & 700 & 9 & & & $5(\min )$ \\
\hline \multicolumn{8}{|c|}{2 варіант } \\
\hline Вогневого впливу & 12 & 0 & 0 & 12 & 0,6 & 4 & 29 \\
\hline Управління & 3 & 0 & 0 & 3 & 0,5 & 10 & 15 \\
\hline Розвідки & 9 & 9 & 450 & 0 & 0,8 & 5 & 0 \\
\hline Разом & 24 & 9 & 450 & 15 & & & 0 (min) \\
\hline \multicolumn{8}{|c|}{3 варіант } \\
\hline Вогневого впливу & 12 & 0 & 0 & 12 & 0,6 & 4 & 29 \\
\hline Управління & 3 & 3 & 300 & 0 & 0,5 & 10 & 0 \\
\hline Розвідки & 9 & 0 & 0 & 9 & 0,8 & 5 & 36 \\
\hline Разом & 24 & 3 & 300 & 21 & & & 0 (min) \\
\hline
\end{tabular}

Висновки. У статті запропоновано подальший розвиток принципу масування PBiA, їх ударів i вогню на найважливіших напрямках 3 урахуванням особливостей внутрішніх воєнних конфліктів останнього часу. Сутність означеного розвитку полягає у зосередженні зусиль РВіА щодо вогневого впливу на ті підсистеми противника, які мають найменші можливості, або найбільш розвідані. Подальший розвиток означеного принципу дає змогу врахувати саму сутність масування - взаємопідсилення ефекту від вогневого впливу. Більш того означений принцип дає змогу переглянути підходи до забезпечення стійкості функціонування системи ВУП і своїх військ, адже враховуючи нерівномірність впливу противника на підсистеми ВУП можна визначити потребу в силах i засобах для виконання поставлених завдань.

Окрім того принцип масування за новою редакцією у разі застосування дасть змогу забезпечити: необхідний ефект від зосередження вогню артилерії на ділянках зосередження основних зусиль (в обороні) та ділянках прориву (у наступі), зменшення витрати боєприпасів для досягнення необхідного ступеня ураження противника.
Подальші дослідження пропонується присвятити переосмисленню теоретикометодологічних засад бойового застосування РВіА під час ВУП, як однієї 3 основних складових системи ВУП.

\section{СПИСОК ВИКОРИСТАНОЇ ЛІТЕРАТУРИ}

1. Матеріали доповідей науково-практичного семінару "Перспективи бойового застосування ракетних військ і артилерії ЗС України". - Львів: ACB, 2015.- 112 c.

2. Матеріали доповідей науково-технічної конференції "Перспективи розвитку ракетних військ і артилерії ЗС України". - Львів: АСВ, 56.11.2014. - $204 \mathrm{c}$.

3. Яковенко В.В. Ураження незаконних збройних формувань підрозділами ракетних військ і артилерії / В.В. Яковенко, О.В. Майстренко, І.Д. Волков, О.В. Вахнін ті ін. - Львів: АСВ. - 2013., $171 \mathrm{c}$.

4. Тенденції розвитку ракетних військ і артилерії на підставі досвіду їх бойового застосування у воєнних конфліктах: матеріали науково-практичного семінару. - К.: НУОУ, 2011. -185 c.

5. Кожевніков В.М. Застосування артилерії у війнах в Афганістані (1979 - 1989 рр.) і Чечні (1994 1996, 1999 - 2000 рр.) 20.02.22. - Військова історія. Дис. на здоб. наук ст. к.іст.н. - К.: 2005. $170 \mathrm{c}$.

6. Ахметов М.Г. Некоторые вопросы планирования огневого поражения в армейских операциях / 
М.Г. Ахметов, А.А. Ходаков // Военная мысль. 1993. - № 4. - С. 34-41.

7. Фесенко Ю.Н. Об особенностях огневого поражения группировок войск / Ю.Н. Фесенко // Военная мысль. - 2000. - № 5. - С. 57-65.

8. Бобриков А. Оценка эффективности огневого поражения ударами ракет и огнем артиллерии / Бобриков А. - СПб. : Галея Принт, 2006. - 424 с.

9. Майстренко О.В. Еволюція змісту принципів застосування військових формувань ракетних військ і артилерії під час вогневого ураження противника / Майстренко О.В., Репіло Ю.С., Адаменко М.В. // Сучасні інформаційні технології у сфері безпеки та оборони. - 2016. - №1. - С. 185-192.

10. Дельбрюк Г. История военного искусства с древнейших времен / Дельбрюк Г. - М.: Эксмо, 2015. - 496 c.
11. Чандлер Д. Военные кампании Наполеона. Триумф и трагедия завоевателя / Чандлер Д. - М.: Центрполиграф, 2011. - 927 с.

12. Т. Г. Гунчак. Друга світова війна // Енциклопедія сучасної України : у 30 т. / ред. кол. I. М. Дзюба [та ін.] ; Національна академія наук України, Наукове товариство імені Шевченка, Координаційне бюро енциклопедії сучасної України НАН України. - К., 2003 - 2014.

13. Ивлев А.А. Основы теории Джона Бойда. Принципы, применение и реализация (Монография) / А.А. Ивлев. - М.: ОРИОН, 2008. $164 \mathrm{c}$.

14. Богданов А.А. Всеобщая организационная наука. Тектология. Кн. 1. / А.А Богданов. - М. : изд Экономика, 1989. - 394 с.

15. Правила стрільби і управління вогнем артилерії. - К.: Варта, 2008.- 256 с.

Стаття надійшла до редакції 22.02.2017

Майстренко А. В., к.воен.н.

Кафедра ракетных войск и артиллерии командно-штабного института применения войск (сил) Национального университета обороны Украины имени Ивана Черняховского, Киев

Дальнейшее развитие принципа массирования ракетных войск и артиллерии, их ударов и огня на важнейших направлениях

Резюме. Статья посвящена дальнейшему развитию принципа массирования ракетных войск и артиллерии, их ударов и огня на важнейших направлениях с учетом особенностей внутренних военных конфликтов последнего времени, основанный на исследовании функционально-организационных цепей системы огневого поражения противника с учетом последовательности выполнения функциональных задач (по теории Бойда) отдельными подсистемами огневого поражения противника.

Ключевые слова: ракетные войска и артиллерия, огневое поражение противника, принцип массирования.

\section{A. Maistrenko, Ph.D}

Command and Staff Institute of troops (forces) of the National Defence University of Ukraine named after Ivan Chernyhovsky, Kyiv

Further development of the principle of massing missile troops and artillery, their shock and fire in key areas

Resume. This article is devoted to the further development of the principle of massing missile troops and artillery, their shock and fire in the most important areas allowing for the internal military conflicts recently, based on the study of functional and organizational chain system fire destruction of the enemy given sequence of functional tasks (in theory Boyd) individual subsystems fire destruction of the enemy.

Keywords: rocket troops and artilleries, fire destruction of the enemy, the principle of massing. 